\title{
Children as victims of trafficking with special reference to sexual exploitation and its ill-effect on psychological \& physical health in Chennai city
}

\section{Introduction}

Trafficking of children or the sale of children is a form of human trafficking and is defined as the "recruitment, transportation, transfer, harboring, and/or receipt" of a child for the purpose of exploitation. Though statistics regarding the magnitude of child trafficking are difficult to obtain, the International Labour Organization estimates that 1.2 million children are trafficked each year. Child trafficking, according to UNICEF is defined as "any person under 18 who is recruited, transported, transferred, harboured or received for the purpose of exploitation, either within or outside a country". There have been many cases where children just disappear overnight, as many as one every eight minutes, according to the National Crime Records Bureau of India. Children are taken from their homes to be bought and sold in the market. In India, there is a large number of children trafficked for various reasons such as labour, begging, and sexual exploitation. Because of the nature of this crime; it is hard to track; therefore making it impossible to have exact figures regarding this issue. India is a prime area for child trafficking to occur, as many of those trafficked are from, travel through or destined to go to India. Most of the trafficking occurs within India, there is also a multitude of children trafficked from Nepal and Bangladesh.

Chennai is one of the leading human trafficking hubs in the country - the key players being scheming travel agents, some business firms which have branches overseas and a section of the entertainment industry which routinely sends people abroad on shooting assignments. All of them cash in the dreams of youth to work in a foreign land. There are different modus operandi adopted by these traffickers. The entertainment industry, especially Kollywood, and business establishments which have branches overseas, use different ways to help / exploit people migrate to foreign countries illegally. ${ }^{1-5}$

Business establishments use their status as an employer to push people out of the country. "These establishments take a hefty fee from prospective migrants and give them false designations. They then create fake experience and professional certificates to substantiate their designation and to aid them to clear the visa interviews. In a majority of the cases, the forgery goes unnoticed and people manage to get out of the country. Some cases get exposed during stringent visa interviews, where the visa officers try to test their knowledge in the subject mentioned in the experience certificate and professional qualifications. Sexual exploitation is a major issue that is faced by many developing countries and is defined as "the sexual abuse of children and youth through the exchange of sex or sexual activities for protection, drugs, shelter, food, other basics of life, and/or money". Often young girls are taken from their homes and sold as items to become sex slaves and even forced into prostitution. This may seem bad enough, but sexual exploitation is not always forced. Out of desperation, some parents will even sell their kids off to be sexually abused, in order to be able to acquire the basic necessities of life. As the parents are likely to have been sexually abused as children,
Volume 5 Issue 2 - 2017

\author{
John Rajadurai P \\ Department of Sociology, University of Madras, India \\ Correspondence: John Rajadurai, Research Scholar, \\ Department of Sociology, University of Madras, Chennai - \\ 600005, India, Email john.mkp@gmail.com
}

Received: July II, 2017 | Published: July 19, 2017

generations to come are forced to live in this seemingly never-ending cycle of selling their children into sexual exploitation and abuse. ${ }^{6-9}$

In 1956, India initiated the Immoral Traffic (Prevention) Act, which prosecutes legally the third parties involved in trafficking. The activities include running of brothel houses, living on earnings from all sexual work, capturing and imprisoning (kidnapping) people into prostitution, etc. This Act failed in the protection the women who may have been forced into prostitution. Furthermore, many were forced from brothels into more dangerous areas. Although this Act made an effort to control trafficking, it was clear that it needed to be reformed.

\section{Some of the problems victims faced include}

\section{Lack of female police}

Studies shows most women are more likely to report sex crimes if female police officers are available. India has historically had a much lower percentage of female police officers than other Asian countries. In Chennai, just 7 percent of police officers are women, and they are frequently given inconsequential posts that don't involve patrol duty, when women do report rape charges to male police, they are frequently demeaned.

\section{Not enough police in general}

There aren't enough police dedicated to protecting ordinary citizens, rather than elites, a Brookings article argues, and the officers that are available often lack basic evidence-gathering and investigative training and equipment.

\section{Blaming of provocative clothing}

There is a tendency to assume the victims of sexual violence somehow brought it on themselves. In a 1996 survey of judges in India, 68 percent of the respondents said that provocative clothing is an invitation to rape. In response to the gang rape incident that happened recently, a legislator in Rajasthan had suggested in banning of skirts as a uniform for girls in private schools, citing it as the reason for increased cases of sexual harassment. 


\section{Acceptance of domestic violence}

The Reuters Trust Law group named India one of the worst countries in the world for women this year, in part because domestic violence there is often seen as deserved. A 2012 report by UNICEF found that 57 percent of Indian boys and 53 percent of girls between the ages of 15 and 19 think wife-beating is justified. A national family-health survey reported that high percentage of women blame themselves for beatings by their husbands.

\section{A lack of public safety}

Women generally aren't protected outside their homes. The gang rape occurred on a bus, and even Indian authorities say that the country's public places can be unsafe for women. Many streets are poorly lit, and there's a lack of women's toilets, a Women and Child Development Ministry report said recently. Women who drink, smoke or go to pubs are widely seen in Indian society as morally loose, and village clan councils have blamed a rise in women talking on cellphones and going to the commercial places such as markets for an increase in the incidence of rape.

\section{Victim stigmatization}

When verbal harassment or groping of women and children do occur in public areas, bystanders and passerby frequently look the other way rather than intervene, both to avoid a conflict and to blame the victim. Politicians contribute to the problem, by making statements that make light of rape or vilify rape victims' supporters.

\section{Encouraging \& pressurization of rape victims to compromise}

In a recent separate rape case, a 17-year-old Indian girl who was allegedly gang-raped killed herself after police pressured her to drop the case against the offender and marry one of the attackers. In most of the North Indian villages rape victims are often encouraged to "compromise" with the family of accused and drop charges by village elders and clan councils, or even to marry the attacker. Such compromises are done by the Village KHAP (is a community organization representing a clan or a group of related clans. This is governed and controlled by the village elders. They are found mostly in northern India) which is aimed at keeping the peace between families or clan groups. According to them a girl's eventual prospects of marriage are thought to be more important than bringing a rapist to justice.

\section{A sluggish court system}

India's court system is painfully slow, in part because of a shortage of judges. The country has about 15 judges for every 1 million people, while China has 159 .

\section{Fewer convictions}

India's conviction rate is no more than 26 percent for rapes that do get reported. There is also no laws or rules on media such as books and magazine covering routine daily sexual harassment, which is euphemistically called "eve-teasing." The passing of a proposed new sexual assault law has been delayed for seven years.

\section{Low status of women}

Perhaps the biggest issue, though, is women's overall lower status in Indian society. For poor families, the need to pay a marriage dowry can make daughters a burden. India has one of the lowest female-tomale population ratios in the world because of sex-selective abortion and female infanticide. Throughout their lives, sons are fed better than their sisters, are more likely to be sent to school and have brighter career prospects. Indian politicians had put forward a slew of potential remedies for India's sexual violence problem. But it's worth noting that it will be hard to end discrimination against women at police stations when it starts in the crib. ${ }^{7-15}$

\section{Objectives of the study on child trafficking are as follows}

i. To examine the limitations faced by the CSWs and child victims in accessing the legal system;

ii. To determine the efforts which are made to combat trafficking of children through prosecution and enforcement against traffickers; and

iii. To understand the protection and assistance is given to victims of trafficking, the problems and difficulties faced by them and their family.

\section{Following are the study design and sample type used to collect the data}

i. Focus group discussions were conducted with child trafficked victims.

ii. Variable taken such as: gender, age at the time of trafficking, medium of trafficking, mode of trafficking, area from where the victim was picked for trafficking, where the children was trafficked (area), years of abuse and confinement, psychological problem faced / facing, physiological health hazards / illness due to abuse and exploitation, rate per day the victims abused, monetary and other basic facilities provided by the Pimps or traffickers, victims status in society, Victims habit $\&$ habitat, etc.

iii. A survey was conducted among 30 victims at the age group of 8 to 16 .

\section{Methodology}

\section{Primary data}

This cross-sectional study was conducted in Rehabilitation Centers of Tamilnadu (India), Chennai. A survey was conducted among 30 victims at the age group of 8 to $16 \cdot{ }^{16-22}$ The data was collected standard scheduled interview method using Quota Sampling technique. The interview questions include 50 questions. These questions covered the following categories:

a. Demographic information,

b. Type of trauma both physiological \& psychological incurred during trafficking \& after abuse.

c. Social approach towards the victim \& victim to Society and ways adopted to overcome it.

\section{Secondary data}

Material was collected from published and unpublished sources such as Research Articles, Journals, Newspaper and Books. Also there had been interaction with NGOs and law enforcement agencies. 


\section{Following are the limitations in the field of research}

i. Indian culture restricts the researcher to ask in-depth questions about sex and sexuality to selected sample.

ii. Biased information from specific gender (Female) due to the influence of culture and stigma issues among peer.

iii. In religious society like India, because of self-report nature of the questionnaire, the honesty of the respondent's responses may be questioned.

iv. Fear of the societal pressure, stigma etc.

\section{Based on the study findings the following recommendations are being made}

In the hope of improving the victims' access to the justice system and helping ameliorate the prevalence of maltreatment /violence against them perpetrated by police and other organs of the state the following legislative, administrative and human rights approaches are suggested:

\section{Legislative}

Strict amendment of ITPA (The Immoral Traffic (Prevention) Act, 1956) by Control Agencies on Traffickers.

\section{Administrative}

i. Regulation - on Sex Trade and other trades related to Sex / Flesh Trade.

ii. Improving working conditions/labour standards - of Licensed Flesh Trade and a check to be kept to stop Trafficking of Human.

iii. Sensitization \& Awareness Programmes for Law Enforcing Agencies

a. Sensitization of the law enforcement agencies, judicial officers and specific government officers, specifically through training to be made mandatory.

b. Preparation of a rights based manual in consultation with NGOs for use by both CSW and law enforcing agencies.

c. Stress on counselling of the victims.

d. 'Raid' and 'rescue' to be differentiated raid is not rights sensitive and is mostly victim centric, whereas rescue is process centric.

e. Presence of a Special Police Officer, social worker, NGO or person from the community in the rescue operation. And immediately after rescue counselling of the girl to give statement to the police against traffickers, whether kotha owners, pimps, factory owners, etc.

f. All public officials suspected of being involved in trafficking are required to be investigated, tried and, if convicted, appropriately punished.

iv. Creation of specialized information technology package to track trafficked/women/children.

v. Border security forces to be alert to trafficking vi. Public awareness campaigns should be initiated.

\section{Human rights approach}

i. Psychological, physical, social and economic needs of the victims to be fulfilled.

ii. Post-rescue rehabilitation should be coupled with counselling. Sustained counselling should be given to the girl rescued till the perpetrators of crime are punished and the girl is finally reintegrated with society. Mental health services to be provided to the traumatized woman, in addition to addressing her basic needs.

iii. Rescued girls who have been abandoned by their families or are homeless should be trained in economically viable vocational trades to ensure economic rehabilitation

iv. Attempts to be made to shift from custodial care to community based care.

v. Explore the possibility of making alternative arrangement of protective homes for rescued girls, and utilizing institutions run by voluntary organizations by way of certification,

vi. Separate institutions to be set up for minors - less than 18 years and adults -18 and above.

vii. Combined efforts should be made by the Police and NGOs to locate addresses for repatriation of the victims.

viii. Repatriation - Repatriation is defined as the restoration, sending back or return of rescued victims to place of origin and/or residence. There should be a healthy and strong collaboration and networking between Governments, Judiciary and concerned NGOs to facilitate the repatriation of the trafficked women and children. Shortage of manpower to repatriate the victims cannot be accepted as an excuse used by the police to escape their responsibility. To be avoided are returning girls to the families who are themselves the perpetrators or abusers or returning them to families and societies not willing to accept them back and where they are likely to suffer further stigma and abuse..$^{22-29}$

\section{Acknowledgments}

None.

\section{Conflicts of interest}

The author declares there are no conflicts of interest.

\section{References}

1. Shailaja A. Going nowhere: Trafficking of women \& children in international sex trade. Dominant Publishers and Distributors, India. 2001 .

2. Latifa A. Trafficking and prostitution. Centre for Women and Children Studies, India. 1997.

3. Aparna B. Report on laws and legal procedures concerning the commercial sexual exploitation of children in Nepal. ECPAT, India. 2004.

4. Radhika C. Integration of the human rights of women and the gender perspective: Violence against women, report of the special rapporteur on violence against women, its causes and consequences, United Nations Economic and Social Council. Popline, India. 2003;1-425. 
5. Edwards SM. Crime in India: A brief review of the more importan offences included in the annual criminal returns with chapters on prostitution and miscellaneous matters. Oxford University Press, USA. $1924 ; 1-169$.

6. Aditi G. Position of migrant women particularly trafficked women and what kind of legal protection is to be given to them. Delhi University, India. 2001.

7. Ruchira G, Ruchi S. Confronting the demand for sex-trafficking: A handbook for law-enforcement. Apne Aap Women Worldwide, India. 2007.

8. Mazhar H. Immoral traffic (prevention) act, 1956 (Eastern Book Company, Lucknow, 1997) India, Human Resource Development, New Delhi: Report of the committee on prostitution, child prostitutes and children of prostitutes and plan of action to combat trafficking and commercial sexual exploitation of women and children. Human Resource Development, India. 1998

9. India, Ministry of Women and Child Welfare, New Delhi: India Country Report: To Prevent and Combat Trafficking and Commercial Sexual Exploitation of Children and Women prepared for the World Congress III against Sexual Exploitation of Children and Adolescents, India. 2008.

10. Gathia J. Child prostitution in India. Concept Publishing Company, India. 1998.

11. Madhu JD. Women and children in prostitution. Uppal Publishing House, India. 1997.

12. Amod KK. Issue and concerns of trafficking in women and children Institute of Juvenile Justice, India. 2002.

13. Ali KM. Street girls and immoral traffic in India. Uppal Publishing House, India.1996.

14. Gunjan K. From bondage to freedom. National Human Rights Commission, India. 2006;1-145.

15. Krishnamurthy K. Trafficking in human beings. Bureau NRM The Hague, USA. $2005 ; 1-168$.
16. Harsh K. Child sexual abuse in India. National Human Rights Commission, India. 2004.

17. Frank L, Elzbieta G. Data and research on human trafficking. International Organization for Migration. 2005;43(1-2):5-16.

18. Ministry of Women and Child Development, New Delhi: Draft National integrated plan of action to prevent and combat human trafficking with special focus on children and women. National Human Rights Commission, India. 2006

19. Mukherji SK. Prostitution in India. Inter-India Publication, India. 1986.

20. Vanessa ME. Stopping traffic? A comparative study of responses to the trafficking in women for prostitution. Br J Criminol. 2006;46(2):318-333.

21. Social violence on women and children in prostitution. National Commission for Women, India. 1996.

22. Women \& child in prostitution. National Commission for Women, India. 1997.

23. Trafficking in persons especial on women and children in Nepal. 2006-07. National Human Rights Commission, India. 2007;1-203.

24. From bondage to freedom: An analysis of international legal regime on human trafficking. National Human Rights Commission, India. 2006;1145 .

25. Mumbai P. Report of the national workshop to review the implementation of laws and policies related to trafficking. Prayas, India. 2004;1-110.

26. Shankar S, Nair PM. Action research on trafficking in women and children in India. UNIFEM, India. 2003.

27. Aparna S. Resource directory of organisations working against human trafficking and related issues. UNIFEM South Asia Office, India. 2003;1124.

28. Nexus of vulnerability. United Nations Development Programme, USA. 2001.

29. Murali S. The Ugly Face of Human Trafficking. The Hindu (Daily News Paper), India. 2016 